\title{
AFTER-SALES SERVICE TO INCREASE CUSTOMER SATISFACTION: APPLICATION OF IMPORTANCE PERFORMANCE ANALYSIS METHOD
}

\author{
Andrianto Susilo ${ }^{1)}$, Ridho Bramulya Ikhsan ${ }^{2)}$ \\ ${ }^{1,2)}$ Management Department, BINUS Online Learning, Bina Nusantara University, Jakarta, 11480, Indonesia \\ Corresponding author: ridho.bramulya.i@binus.ac.id
}

\begin{abstract}
This research will assess customer satisfaction with after-sale services for customers who use interior design services in Jakarta. This type of study is qualitative descriptive with survey data collection techniques-the data survey collected by cross-sectional. The data collection method uses a questionnaire distributed to 100 customers who used interior design services in Jakarta. The analytic approach used is ImportancePerformance Analysis (IPA). The results of the research have successfully identified customer satisfaction with the after-sales service. There are 6 out of 20 attributes perceived as unsatisfied customers, while other attributes are perceived to be moderately satisfied and satisfied by interior design service customers in Jakarta.
\end{abstract}

Keywords: After-Sales Service, Customer Satisfaction, Importance-Performance Analysis, Design Interior.

\section{Introduction}

The intense competition in the business world requires every company to develop business strategies and customer-oriented marketing strategies. Firms must be able to create customer value that is higher than their competitors to provide customer satisfaction. Today, we consider customer satisfaction very important because it shows how the firm was providing quality products or services to its customers. Pleasant customers are a thing of the primary aims of the firm and the after-sales service. (Murali, Pugazhendhi, \& Muralidharan, 2016).

In current years, the product-service system has arisen as an idea to control product functionality for consumers during the product life cycle, confirmed by physical products and fit services. The product-service system is a new concept, and after-sales service can as part of the product and service system concept (Murali et al., 2016). The idea of after-sales service is still a focus of study because it contributes to building satisfaction and establishing sustainable relationships with customers. (Ahn \& Sohn, 2009; Geng \& Chu, 2012; Kurata \& Nam, 2010; Markeset \& Kumar, 2003; Pezzotta, Cavalieri, \& Gaiardelli, 2012).

Sales service has grown a necessary factor for all business actions. The firm has a combined marketing mix in complex ways to build customer delight and loyalty. The firm strives to implement superior after-sales service to customers and uses different methods to sustain customer loyalty. Many studies of after-sales service review the correlation within after-sales service, customer delight, and commitment in various settings. (Choudhary, Asif, Choudhry, Siddique, \& Mughal, 2011; Goffin, 1999; Murali et al., 2016; Shaharudin, Yusof, Elias, \& Mansor, 2010). However, there is not much literature on post-sale services in the interior design services sector..

In managing a business, after-sales activities have a strategic role in creating durable goods (Persson \& Saccani, 2009). Examining customer satisfaction with after-sales service can identify possibilities for improvement so that the right strategy will create to develop customer satisfaction. Customer satisfaction can increase demand for products or services as well as a firm or brand reputation. When a firm plans to sell products efficiently, it must do fit planning for after-sales service, and the devising is part of customer relationship management (Vitasek, 2005).

\section{Literature Review \\ Customer Satisfaction}

Customer satisfaction is the output of service quality; that is, customers compare expectations and perceived performance. If the firm can meet the needs and expectations of customers, we can be sure that it has been able to satisfy its customers. Satisfied customers are the ultimate goal of every business action because they have a possible impact on the repeat buying behavior and gains (Kim, Li, \& Brymer, 2016; Ryu, Lee, \& Gon Kim, 2012). Many studies of customer satisfaction in the service industry have allowed that pleasure is an emotive or cognitive construct (Martin, O'Neill, Hubbard, \& Palmer, 2008). Meantime, any researchers argue that both emotions and cognition are elements of happiness (Ali, Ryu, \& Hussain, 2016; Kollmann, 2000), which must be considered different from the model of consumer behavior in service settings (Wong, 2004). Researchers have recommended that measures of customer satisfaction must add an affective component (Martin et al., 2008).

Satisfaction is a feeling that arises, happy, or disappointed after comparing the perception or impression of the performance of a product or service and expectations (Kotler \& Keller, 2015). Customer satisfaction has been studied in the prior study as a unidimensional construct that measures overall satisfaction with the 
company's services as a result of an aggregate assessment of all interactions and points of contact with the firm (Chen \& Tsai, 2008; Yang \& Peterson, 2004). One of the main goals for companies in providing services is the formation of satisfied customers. The long-term effects of satisfied customers are positive commentaries by word-of-mouth, customer dedication, and sustainable profitability (Greenwell, Fink, \& Pastore, 2002; Liu \& Jang, 2009). We conclude that satisfaction is a function of perception of performance and expectations which includes the difference between expectations and performance.

\section{After-Sales Service}

After-sales service is vital to satisfy and engage customers (Choudhary et al., 2011). After-sales service quality has an actual impact on perceived value, behavioral intentions, and customer delight (Rigopoulou Irini, Chaniotakis Ioannis, Lymperopoulos, \& Siomkos George, 2008). Besides, after-sales service is vital for firms to sustain customer loyalty (Nasir, Mushtaq, \& Rizwan, 2014). The firms can design, manage, and build customer loyalty by implementing best after-sales services, such as rapid replies to customer complaints, replacing damaged goods, or exchanging money if customers are unhappy with a product or service (Nasir et al., 2014). It proves that there is a significant correlation between after-sales service and customer satisfaction (Maghsoudlou, Mehrani, \& Azma, 2014).

After-sales service is a facility after the product or service used by customers (Saladin, 2003). Moreover, after-sales service is provided to customers after the sale is made by giving repair and maintenance services (Kotler \& Keller, 2015). After-sales service is a series of activities covering all areas of the integrated business to deliver products and services so that they perceive as satisfying by customers and realizing company goals (Arief, 2007). We conclude that after-sales service is the customer uses a service provided to meet customer needs after a sales transaction, both in terms of repair and maintenance after the product or service.

Maintenance and improvement are essential elements of after-sales service (Loomba, 1996). One way to get a fast customer response is to offer loan products (if possible), mainly product or service loss. (Loomba, 1996), so maintenance requirements correct before an error occurs. According to the Indonesian National Standard - SNI (2007), types of after-sales service: post-sale after-sales service and after-sales service during the warranty period. Customers' desires are not only limited to the service before and during the purchase, but have also increased to post-purchase services (Nasution, Sudarso, \& Trisunarno, 2006). After-sales service for the goods and manufacturing industries is necessary, even competing in providing the best service for customers. Guarantees or guarantees are attractive offers for customers. Each customer needs to be explained about the warranty provided. Example, time or warranty period; the range of warranties, whether included certain spare parts and parts that are replaced or only repair services provided; limits on the cause of mechanical damage; warranty administration procedures; the willingness of professional technicians and equipment; and place of complaint or service (Nasution et al., 2006).

\section{Research Method}

We collected research data from questionnaires arranged in a structured and closed manner by splitting two columns. The first column is the importance of consumers, and the second column is the performance believed by consumers. Respondents were asked to answer each question by matching importance and perceived performance. A five-point Likert scale is used to measure after-sales service indicators. This study's population has customers who have used interior design services in Jakarta with an unknown amount. Determination of the minimum sample size using the Lemeshow approach with a margin of error of $10 \%$, a $\mathrm{Z}$ score at df $95 \%$, and an estimated maximum of 0.5 got a sample size of 100 respondents. The sampling technique used is probability sampling with simple random sampling. After-sales service measurement consists of 20 attributes (Murali et al., 2016).

Table 1. Measurement Variable

\begin{tabular}{|c|c|}
\hline Variable & Attribute \\
\hline \multirow[t]{13}{*}{ After-sales service } & 1. Persistence in the keeping of service quality \\
\hline & 2. Coverage in service choices \\
\hline & 3. Equipment available in giving services \\
\hline & 4. A reasonable guarantee policy \\
\hline & 5. Providing required spare-parts \\
\hline & 6. Openness to service centers \\
\hline & 7. Facilities for registering criticisms \\
\hline & 8. Responsive to customer criticisms \\
\hline & 9. The time needed to resolve criticisms \\
\hline & 10. Provision of services as agreed \\
\hline & 11. Fair service costs \\
\hline & 12. Convenience to services \\
\hline & 13. Convenience to contact service \\
\hline
\end{tabular}




\begin{tabular}{ll}
\hline \multicolumn{1}{c}{ Variable } & \multicolumn{1}{c}{ Attribute } \\
\hline & $\begin{array}{l}\text { 14. Understand customer needs } \\
\text { 15. Customer handling }\end{array}$ \\
\hline $\begin{array}{l}\text { 16. The attitude of employee professionalism in serving } \\
\text { 18. Interpersonal behavior of serving employees }\end{array}$ \\
\hline $\begin{array}{l}\text { 19. Service document availability } \\
\text { 20. Availability of information and consultation at the service center }\end{array}$ \\
\hline
\end{tabular}

The questionnaire was developed from attributes, then tested for its level of validation using inter-item correlation. Questionnaire items are declared valid, ideally having a value of 0.2-0.4 (Piedmont, 2014). While the reliability of the questionnaire was tested with Cronbach Alpha with a reliability cut-off value of 0.7 (Nunnally, 1978).

This research used Importance Performance Analysis (IPA). The primary target of this investigation is to find a match between the level of the firm performance in providing services with customer importance for after-sales service. The level of suitability that determines the priority of improving after-sales service performance in satisfying customers (Martilla \& James, 1977).

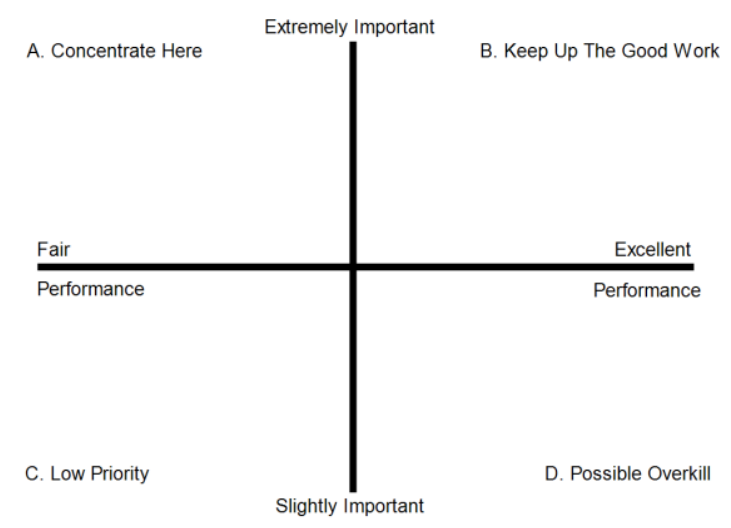

Figure 1. IPA Matrix (Martilla \& James, 1977)

\section{Result and Discusssion Instrument Testing}

We have tested research data for validity and reliability. Overall, it has declared all statement in the performance column is valid because the inter-item correlation value is between the range 0.20-0.40 and over 0.40 (Piedmont, 2014) and reliable because the Cronbach Alpha value is 0.951>0.7. It declares all statement in the importance column valid because the inter-item correlation value is between $0.206-0.970$ and is also reliable because the Cronbach Alpha value is 0.950> 0.7. The questionnaire used was appropriate for measuring after-sale services. We present the validity test results in table 2 and table 3 .

Table 2. Inter-Item Correlation - Performance

\begin{tabular}{|c|c|c|c|c|c|c|c|c|c|c|c|c|c|c|c|c|c|c|c|c|c|c|}
\hline Item & Mean & $\begin{array}{c}\text { Std. } \\
\text { Deviation }\end{array}$ & P1 & P2 & P3 & P4 & P5 & P6 & P7 & P8 & P9 & P10 & P11 & P12 & P13 & P14 & P15 & P16 & P17 & P18 & P19 & P20 \\
\hline P2 & 2.270 & 0.679 & & 1.000 & .647 & .606 & .622 & .749 & .730 & .638 & .333 & .307 & .353 & .300 & .246 & .331 & .350 & .321 & .294 & .314 & .345 & .441 \\
\hline P3 & 3.030 & 0.717 & & & 1.000 & .970 & .837 & .764 & .822 & .600 & .532 & .442 & .502 & .447 & .322 & .392 & .415 & .330 & .434 & .339 & .483 & .508 \\
\hline P5 & 2.840 & 0.748 & & & & & 1.000 & .693 & .716 & .611 & .588 & .482 & .555 & .509 & .463 & .501 & .413 & 432 & 443 & .335 & .525 & .539 \\
\hline P6 & 2.270 & 0.649 & & & & & & 1.000 & .811 & .691 & .514 & .437 & .537 & .475 & .345 & .397 & .502 & .410 & .435 & .421 & .440 & .553 \\
\hline P7 & 2.130 & 0.661 & & & & & & & 1.000 & .696 & .448 & .398 & .488 & .426 & .312 & .362 & .463 & .444 & .423 & .347 & .401 & .497 \\
\hline P11 & 3.240 & 0.653 & & & & & & & & & & & 1.000 & .825 & .732 & .675 & .715 & .528 & .398 & .531 & .498 & .400 \\
\hline P12 & 2.160 & 0.677 & & & & & & & & & & & & 1.000 & .688 & .622 & .607 & .526 & 303 & .430 & .447 & .366 \\
\hline P13 & 3.270 & 0.709 & & & & & & & & & & & & & 1.000 & .574 & .633 & .554 & .340 & .450 & .476 & .402 \\
\hline P14 & 2.350 & 0.609 & & & & & & & & & & & & & & 1.000 & .656 & .495 & 326 & .342 & .464 & .318 \\
\hline P15 & 3.350 & 0.575 & & & & & & & & & & & & & & & 1.000 & .470 & .394 & .415 & .380 & .492 \\
\hline P16 & 2.340 & 0.639 & & & & & & & & & & & & & & & & 1.000 & .206 & .427 & .322 & .284 \\
\hline
\end{tabular}

Cronbach Alpha: 0.951 
Table 3. Inter-Item Correlation - Importance

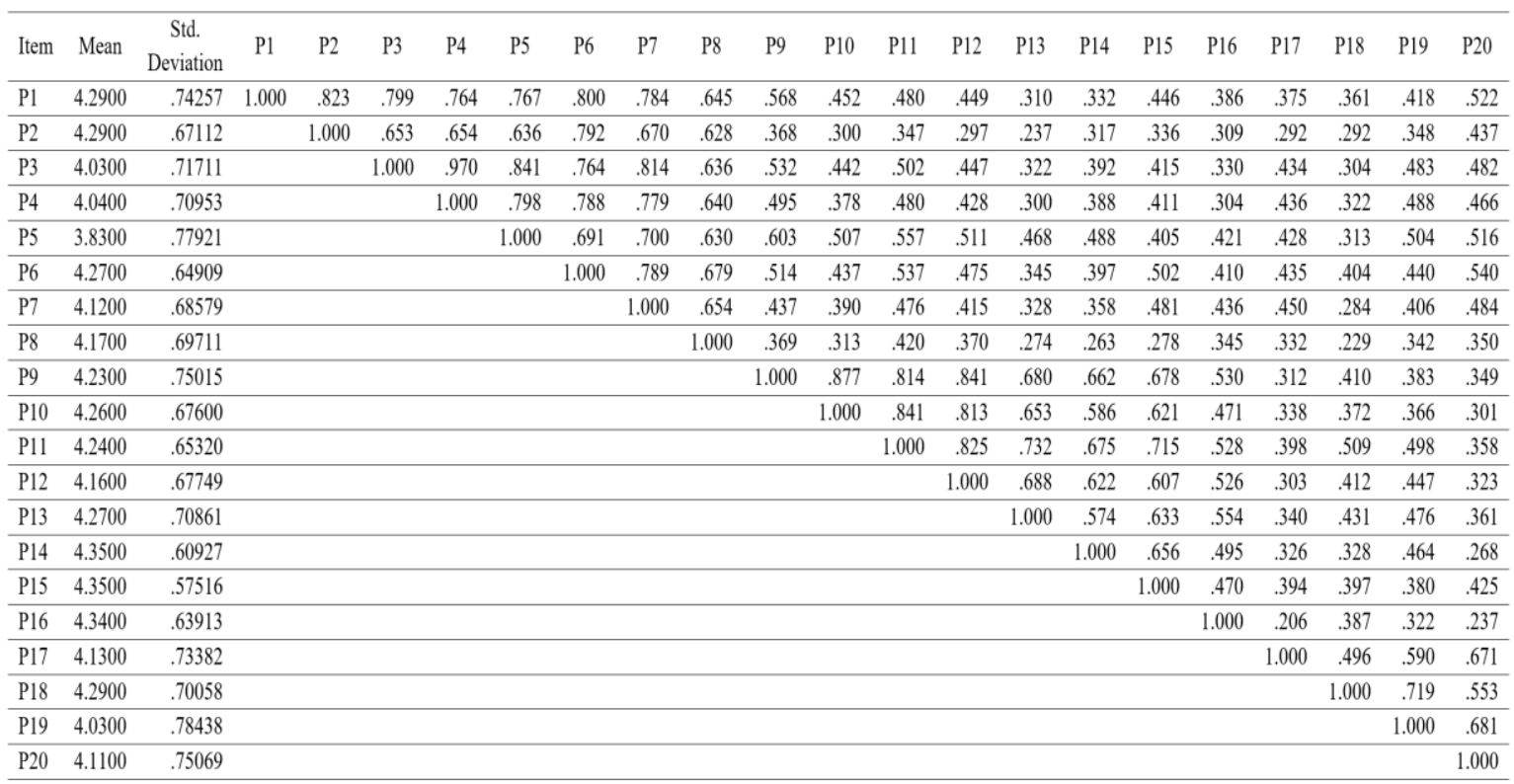

Cronbach Alpha: 0.950

\section{Measurement of Importance-Performance Analysis (IPA)}

To determine the after-sales service attributes placement, we use a cartesian diagram split into four quadrants, i.e., concentrate here (A), keep up the good work (B), low priority (C), and possible overkill (D). The measurement results of the after-sales service attributes allow the firm to increase customer satisfaction based on the after-sales service attributes. To determine the after-sales service attributes position in a Cartesian diagram, we first calculate the mean value of performance and importance.

Table 4. After-Sales Service Attributes, Mean and Gap Score

\begin{tabular}{|c|c|c|c|c|}
\hline Variable & Attributes & $\begin{array}{c}\text { Mean } \\
\text { Performance }\end{array}$ & $\begin{array}{c}\text { Mean } \\
\text { Importance }\end{array}$ & $\begin{array}{l}\text { Gap } \\
\text { Score }\end{array}$ \\
\hline \multirow{20}{*}{$\begin{array}{l}\text { After- } \\
\text { sales } \\
\text { service }\end{array}$} & 1. Persistence in the keeping of service quality & 2.31 & 4.29 & -1.98 \\
\hline & 2. Coverage in service choices & 2.27 & 4.29 & -2.02 \\
\hline & 3. Equipment available in giving services & 3.03 & 4.03 & -1.00 \\
\hline & 4. A reasonable guarantee policy & 3.04 & 4.04 & -1.00 \\
\hline & 5. Providing required spare-parts & 2.84 & 3.83 & -0.99 \\
\hline & 6. Openness to service centers & 2.27 & 4.27 & -2.00 \\
\hline & 7. Facilities for registering criticisms & 2.13 & 4.12 & -1.99 \\
\hline & 8. Responsive to customer criticisms & 2.20 & 4.17 & -1.97 \\
\hline & 9. The time needed to resolve criticisms & 3.23 & 4.23 & -1.00 \\
\hline & 10. Provision of services as agreed & 3.26 & 4.26 & -1.00 \\
\hline & 11. Fair service costs & 3.24 & 4.24 & -1.00 \\
\hline & 12. Convenience to services & 2.16 & 4.16 & -2.00 \\
\hline & 13. Convenience to contact service & 3.27 & 4.27 & -1.00 \\
\hline & 14. Understand customer needs & 2.35 & 4.35 & -2.00 \\
\hline & 15. Customer handling & 3.35 & 4.35 & -1.00 \\
\hline & 16. The attitude of employee professionalism in serving & 2.34 & 4.34 & -2.00 \\
\hline & $\begin{array}{l}\text { 17. Technical competence of employees in providing } \\
\text { services }\end{array}$ & 3.13 & 4.13 & -1.00 \\
\hline & 18. Interpersonal behavior of serving employees & 2.29 & 4.29 & -2.00 \\
\hline & 19. Service document availability & 3.03 & 4.03 & -1.00 \\
\hline & $\begin{array}{l}\text { 20. Availability of information and consultation at the } \\
\text { service center }\end{array}$ & 2.14 & 4.11 & -1.97 \\
\hline
\end{tabular}




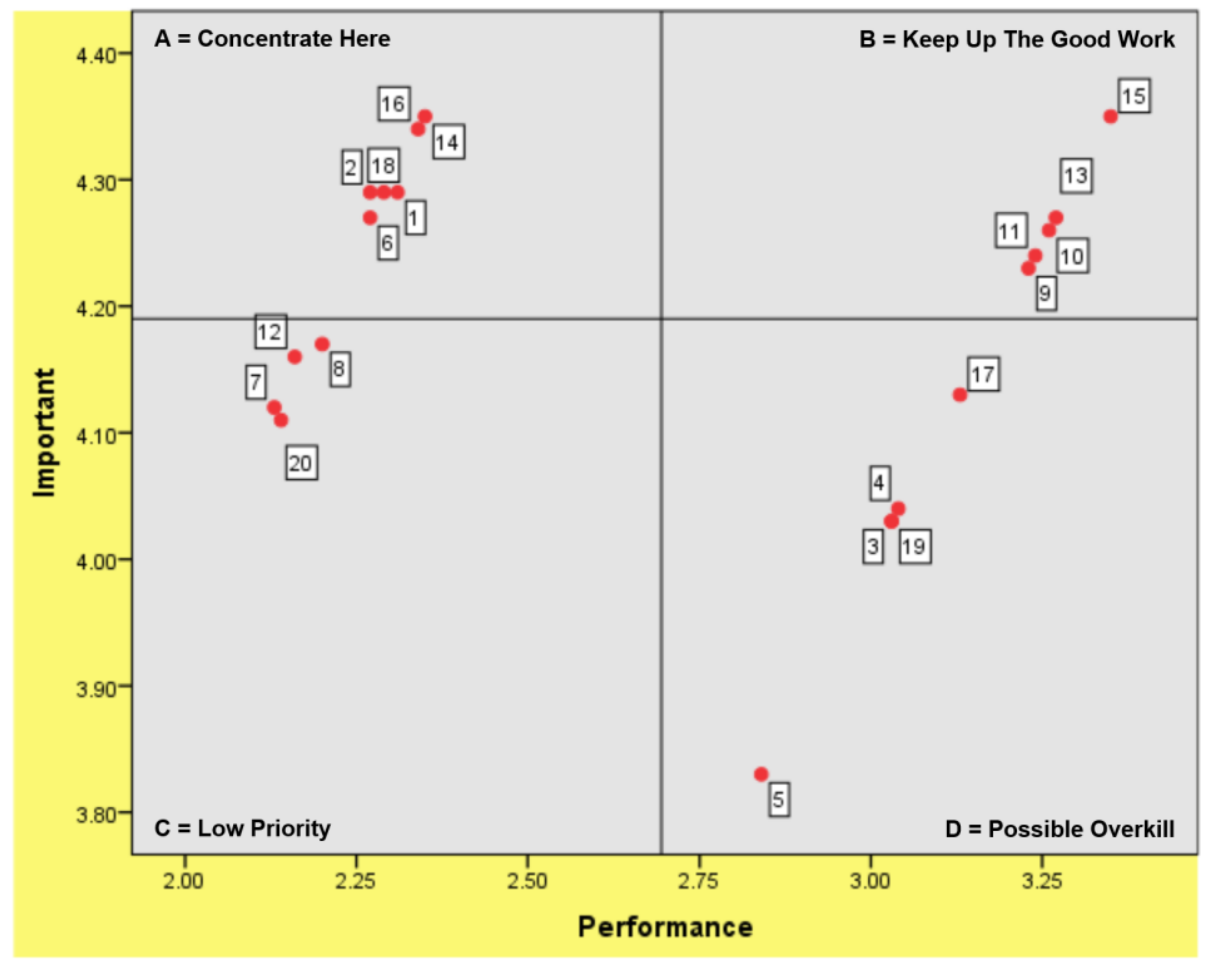

Figure 2. IPA Matrix For After Sales Service

The results of mean after-sales service performance and customer importance about attributes that affect after-sales service satisfaction show that the firm is still not meeting customer expectations.

1. Concentrate here

This quadrant shows that the attributes need to get top priority because they are considered very important by interior design service customers. However, the performance of after-sales services is still not satisfactory. The attributes in this quadrant are: persistence in the keeping of service quality (attribute 1), coverage in service choices (attribute 2), openness to service centers (attribute 6), understand customer needs (attribute 14), the attitude of employee professionalism in serving (attribute 16), and interpersonal behavior of serving employees (attribute 18)

2. Keep up the good work

The firm must maintain attributes in this quadrant because the level of implementation or quality of aftersales service is following the performance of interests and customer expectations. Hence, the firm must maintain the quality of post-sale service at this time. The attributes in this quadrant are: the time needed to resolve criticisms (attribute 9), provision of services as agreed (attribute 10), fair service costs (attribute 11), convenience to contact service (attribute 13), and customer handling (attribute 15).

3. Low priority

This quadrant shows that attributes are considered low priority by interior design service customers, while the quality of after-sale services is quite good. The indicators in this quadrant are: cacilities for registering criticisms (attribute 7), responsive to customer criticisms (attribute 8), convenience to services (attribute 12), and availability of information and consultation at the service center (attribute 20)

4. Possible overkill

Attributes in this quadrant are considered not too valuable by the customer, but the firm has provided more or very satisfying services. It is sometimes regarded as excessive by interior design service customers. The indicators in this quadrant are: equipment available in giving services (attribute 3), a reasonable guarantee policy (attribute 4), providing required spare-parts (attribute 5), technical competence of employees in providing services (attribute 17) and service document availability (attribute 19)

\section{Discussion}

The result of the Importance Performance Analysis (IPA) matrix explains that the firm is still inconsistent in providing after-sales services to its customers. There are six out of twenty attributes of post-sale services that consumers consider to have poor performance. In practice, the firm has not been wholly consistent in providing after-sale services and has been impressed by discriminating customers who only take the cheapest interior design service packages. This condition is very unfavorable for the firm because no matter how small, they must give the service used by the customer in after-sale services. The range of service choices becomes an attribute that needs to be improved. Customers feel relaxed and comfortable in dealing with employees who provide services. However, employee implementation is often difficult to contact and behaves less pleasantly in 
providing after-sale services, giving the impression that employees lack polite behavior. Accessibility to service centers in the third attribute that needs attention to be improved. Accessibility to the service center means that the service office has a problematic location for customers to find (less strategic). We also perceive understanding customer needs is also as dissatisfied by the customer. It is often a misunderstanding between the firm and the customer in terms of the design desired by the customer. Still, the firm does not meet customer demand, and lack of reading customer wishes in interior design needs. We perceive the attitude of employee professionalism in serving customers as dissatisfied by customers who are less committed to completing work and seem to be in a hurry to provide design results that are not optimal. It also perceives interpersonal behavior attribute of serving employees are also as dissatisfied by customers because employees cannot establish good relations with customers during the interior design process. Often customers want design changes, but employees do not respond well to customer requests.

This research adopted all the attributes used by Murali et al. (2016) in identifying after-sales service to create customer satisfaction. Murali et al. (2016) identified ten attributes that received major attention, i.e., a reasonable guarantee policy (attribute 4); providing required spare-parts (attribute 5), openness to service centers (attribute 6), facilities for registering criticisms (attribute 7), responsive to customer criticisms (attribute 8), the time needed to resolve criticisms (attribute 9), provision of services as agreed (attribute 10), convenience to services (attribute 12), convenience to contact service (attribute 13), and understand customer needs (attribute 14). This research, six attributes need major attention, i.e., persistence in the keeping of service quality (attribute 1), coverage in service choices (attribute 2), openness to service centers (attribute 6), understand customer needs (attribute 14), the attitude of employee professionalism in serving (attribute 16), and interpersonal behavior of serving employees (attribute 18). Similarities between Murali et al. (2016) and this research are two attributes that perceived as unsatisfied, i.e., openness to service centers (attribute 6) and understanding customer needs (attribute 14).

To increase satisfaction with after-sales service from customers who use interior design services, we recommend that firms have a consistent attitude in keeping after-sales service to customers by not prejudging against customers. Besides, employees must be easy to communicate and have a pleasant manner to give aftersales service. Firms must create a guarantee policy that is more flexible following customer contracts and makes it easier for customers to reach service centers. Providing facilities to file criticisms about services is also essential. Employees must respond to every customer criticism by making it easy to contact the service agency and find out all customer needs for design trends. The attitude of employee professionalism also needs to be improved when handling customers, such as behaving well when serving customers and ensuring that any suggestions from customers follow up quickly and accurately.

\section{Conclusion and Recommendation}

Finally, we conclude that firms need to pay attention to three key things: providing after-sales service, making customers feel comfortable dealing during the design work process, and treating customers well and kindly. Firms desire to open branches that are easily accessed by customers. Besides, employees must learn all customer needs, enhance professionalism in serving customers, and are always committed to completing work. Employees need to establish good relationships with customers during the interior design process.

\section{References}

Ahn, J. S., \& Sohn, S. Y. (2009). Customer pattern search for after-sales service in manufacturing. Expert Systems with Applications, 36(3, Part 1), 5371-5375. doi:https://doi.org/10.1016/j.eswa.2008.06.061

Ali, F., Ryu, K., \& Hussain, K. (2016). Influence of Experiences on Memories, Satisfaction and Behavioral Intentions: A Study of Creative Tourism. Journal of Travel \& Tourism Marketing, 33(1), 85-100. doi:10.1080/10548408.2015.1038418

Arief, M. (2007). Pemasaran jasa dan kualitas pelayanan. Malang: Bayumedia Publishing.

Chen, C.-F., \& Tsai, M.-H. (2008). Perceived value, satisfaction, and loyalty of TV travel product shopping: Involvement as a moderator. Tourism Management, 29(6), 1166-1171. doi:https://doi.org/10.1016/j.tourman.2008.02.019

Choudhary, A. I., Asif, M., Choudhry, R. M., Siddique, Z., \& Mughal, A. (2011). Impact of after sale service characteristics on customer satisfaction. Information management business review, 3(6), 360-365. doi:https://doi.org/10.22610/imbr.v3i6.952

Geng, X., \& Chu, X. (2012). A new importance-performance analysis approach for customer satisfaction evaluation supporting PSS design. Expert Systems with Applications, 39(1), 1492-1502. doi:https://doi.org/10.1016/j.eswa.2011.08.038

Goffin, K. (1999). Customer support: A cross-industry study of distribution channels and strategies. International Journal of Physical Distribution \&amp; Logistics Management, 29(6), 374-398. doi:10.1108/09600039910283604

Greenwell, T. C., Fink, J. S., \& Pastore, D. L. (2002). Assessing the Influence of the Physical Sports Facility on Customer Satisfaction within the Context of the Service Experience. Sport Management Review, 5(2), 129-148. doi:https://doi.org/10.1016/S1441-3523(02)70064-8 
Kim, W. G., Li, J., \& Brymer, R. A. (2016). The impact of social media reviews on restaurant performance: The moderating role of excellence certificate. International Journal of Hospitality Management, 55, 4151. doi:https://doi.org/10.1016/j.ijhm.2016.03.001

Kollmann, T. (2000). The price/acceptance function: perspectives of a pricing policy in European telecommunication markets. European Journal of Innovation Management, 3(1), 7-15. doi: $10.1108 / 14601060010305210$

Kotler, P., \& Keller, K. L. (2015). Marketing Management (15 ed.): Pearson Education, Limited.

Kurata, H., \& Nam, S.-H. (2010). After-sales service competition in a supply chain: Optimization of customer satisfaction level or profit or both? International Journal of Production Economics, 127(1), 136146. doi:https://doi.org/10.1016/j.ijpe.2010.05.005

Liu, Y., \& Jang, S. (2009). Perceptions of Chinese restaurants in the U.S.: What affects customer satisfaction and behavioral intentions? International Journal of Hospitality Management, 28(3), 338-348. doi:https://doi.org/10.1016/j.ijhm.2008.10.008

Loomba, A., P. S. (1996). Linkages between product distribution and service support functions. International Journal of Physical Distribution \&amp; Logistics Management, 26(4), 4-22. doi:10.1108/09600039610116486

Maghsoudlou, Z., Mehrani, H., \& Azma, F. (2014). The role of after-sales service in customer satisfaction: case study (Samsung house appliances). International Research Journal of Management Sciences, 2(6), 175-179.

Markeset, T., \& Kumar, U. (2003). Design and development of product support and maintenance concepts for industrial systems. Journal of Quality in Maintenance Engineering, 9(4), 376-392. doi: $10.1108 / 13552510310503231$

Martilla, J. A., \& James, J. C. (1977). Importance-Performance Analysis. Journal of Marketing, 41(1), 77-79. doi:10.1177/002224297704100112

Martin, D., O'Neill, M., Hubbard, S., \& Palmer, A. (2008). The role of emotion in explaining consumer satisfaction and future behavioural intention. Journal of Services Marketing, 22(3), 224-236. doi:10.1108/08876040810871183

Murali, S., Pugazhendhi, S., \& Muralidharan, C. (2016). Integration of IPA and QFD to assess the service quality and to identify after sales service strategies to improve customer satisfaction - a case study. Production Planning \& Control, 27(5), 394-407. doi:10.1080/09537287.2015.1129463

Nasir, A., Mushtaq, H., \& Rizwan, M. (2014). Customer loyalty in telecom sector of Pakistan. Journal of Sociological Research, 5(1), 449-467.

Nasution, A. H., Sudarso, I., \& Trisunarno, L. (2006). Manajemen Pemasaran untuk Engineering. Yogyakarta: CV ANDI OFFSET.

Nunnally, J., C. (1978). Psychometric Theory (2 ed.): McGraw-Hill.

Persson, F., \& Saccani, N. (2009). Managing the after-sales logistic network-a simulation study. Production Planning \& Control, 20(2), 125-134. doi:10.1080/09537280802707530

Pezzotta, G., Cavalieri, S., \& Gaiardelli, P. (2012). A spiral process model to engineer a product service system: An explorative analysis through case studies. CIRP Journal of Manufacturing Science and Technology, 5(3), 214-225. doi:https://doi.org/10.1016/j.cirpj.2012.07.008

Piedmont, R., L. (2014). Inter-item correlations. In Encyclopedia of Quality of Life and Well-Being Research (pp. 3303-3304). Netherlands: Springer.

Rigopoulou Irini, D., Chaniotakis Ioannis, E., Lymperopoulos, C., \& Siomkos George, I. (2008). After-sales service quality as an antecedent of customer satisfaction: The case of electronic appliances. Managing Service Quality: An International Journal, 18(5), 512-527. doi:10.1108/09604520810898866

Ryu, K., Lee, H. R., \& Gon Kim, W. (2012). The influence of the quality of the physical environment, food, and service on restaurant image, customer perceived value, customer satisfaction, and behavioral intentions. International Journal of Contemporary Hospitality Management, 24(2), 200-223. doi:10.1108/09596111211206141

Saladin, D. (2003). Intisari Pemasaran dan Unsur-unsur Pemasaran (3 ed.). Bandung: Linda Karya.

Shaharudin, M. R., Yusof, K. M. M., Elias, S. J., \& Mansor, S. W. (2010). Factors affecting customer satisfaction in after-sales service of Malaysian electronic business market. Canadian Social Science, 5(6), 10-18. doi:http://dx.doi.org/10.3968/j.css.1923669720090506.002

Vitasek, K. (2005). Supply Chain and Logistics: Council of Supply Chain Management Professionals.

Wong, A. (2004). The role of emotional satisfaction in service encounters. Managing Service Quality: An International Journal, 14(5), 365-376. doi:10.1108/09604520410557976

Yang, Z., \& Peterson, R. T. (2004). Customer perceived value, satisfaction, and loyalty: The role of switching costs. Psychology \& Marketing, 21(10), 799-822. doi:doi:10.1002/mar.20030 